\title{
Hepatotoxic Effect of Aqueous Extract of Parkia biglobosa Seeds on Adult Albino Wistar Rats
}

\author{
Mba Christian Ejuiwa', Kebe Edet Obeten ${ }^{2 *}$, Ozioko Onyinye Mary ${ }^{1}$, Ajaba Anthony Okim $^{2}$, Ozioko Uche \\ Sebastine ${ }^{1}$ \\ ${ }^{1}$ Department of Anatomy, Enugu State University of Science and Technology, Enugu, Nigeria \\ ${ }^{2}$ Department of Anatomy and Forensic Anthropology, Cross River University of Technology, Okuku, Nigeria
}

\begin{abstract}
*Address for Correspondence: Dr. K. E. Obeten, Department of Anatomy and Forensic Anthropology, Cross River University of Technology, Okuku, Nigeria

E-mail: fredobeten@yahoo.com
\end{abstract}

Received: 19 Aug 2021/ Revised: 11 Nov 2021/ Accepted: 29 Dec 2021

\begin{abstract}
Background: Parkia biglobosa belongs to the plant family Fabaceae and is popularly known as the African locust bean tree is gotten from medium-sized, tree high $(20-20 \mathrm{~cm})$, whose leaves are edible and are used in many African local dishes. The phytochemical screening of the methanolic extracts of $P$. biglobosa revealed the presence of saponins, tannins, terpenes, and phenols, reducing sugars, sterols, flavonoids.

Methods: 21 adult Wistar rats (100-120 g) were distributed into 3 groups (A, B and C) consisting of 7 in each. Group B and C were administered orally with aqueous seed extract of $P$. biglobosa at a dose of $300 \mathrm{mg} / \mathrm{kgB}$ wt and $500 \mathrm{mg} / \mathrm{kg} \mathrm{B} \mathrm{wt}$, respectively for 30 days. Group A was normal control and received $300 \mathrm{mg} / \mathrm{kgB}$ wt of normal saline. After 30 days, the weights were recorded and the animals were sacrificed using cervical dislocation. The changes in body weight, liver histology and enzymes were evaluated.

Results: This study shows a significant difference $(p<0.01)$ in the body weight gain between animals in the low, high and control groups respectively. Photomicrograph of the liver tissue from animals in low dose reveals a liver cytoarchitecture with mildly dilated sinusoids, while the liver tissue from animals high dose group revealed a portal tract with dilated sinusoids. Results from histochemical observation of the liver of the control group showed marked periodic Acid Schiff (PAS) staining on predominant hepatocytes but little or no staining of cytoplasm, the low dose reveals a mild PAS staining while that of high dose shows moderate staining on tissue degeneration. Serum chemistry revealed a significant increase $(p<0.05)$ AST and ALT in the test groups when compared to control group.

Conclusion: Results from this study shows that the aqueous extract of $P$. biglobosa at a dose of $500 \mathrm{mg} / \mathrm{kgB}$ wt over 30 days may have adversely affected the morphology of the liver with the increase in serum levels.
\end{abstract}

Key-words: Liver cytoarchitecture, Hepatocytes, Hepatotoxic liver, Parkia biglobosa, Wistar rat

\section{INTRODUCTION}

Medicinal plants play an important role in the management of people health around the world even in developing countries ${ }^{[1]}$. The Sushruta Samhita attributed to the Sushruta in the $6^{\text {th }}$ century B.C. describes 700 medicinal plants, 64 preparations from mineral sources, and 57 preparations based on animal sources ${ }^{[2]}$.

\section{How to cite this article}

Ejuiwa MC, Obeten KE, Mary OO, Okim AA, Sebastine OU. Hepatotoxic Effect of Aqueous Extract of Parkia biglobosa Seeds on Adult Albino Wistar Rats. SSR Inst. Int. J. Life Sci., 2022; 8(1): 29402946.

Access this article online
https://iijls.com/

Nigeria is blessed with indigenous plants, which serve as herbal medicine to cure disease and heal injuries ${ }^{[3]}$ including P. biglobosa (African locust bean). In Nigeria, which has many languages, it is called nere or iru in Yoruba, Origiri in Igbo and Dorwora in Hausa languages. It is a perennial deciduous tree of the Fabacceae family and is commonly found in varieties of habitats in Africa and it mostly grows on its own. The seeds of $P$. biglobosa also play an important role in the economic life of locals in Nigeria as it is being sold in local markets which the indigenous people use as edibles. The seeds contain $29 \%$ lipids, 35\% proteins and $16 \%$ carbohydrates and have also been reported to serve as a good source of fat and calcium ${ }^{[4]}$. 
The liver is a metabolic organ in the abdomen that plays a vital role in the general body functions from digestion to the storage of certain biological compounds. The activity of the liver connects to various tissues across the systems to maintain homeostasis. After food is ingested and digested in the gastrointestinal tract, the liver helps to properly distribute and absorb various biological compounds including glucose, fatty acids, and amino acids into the bloodstream. Remains of these compounds are then sent to the liver through the portal vein circulation system ${ }^{[5]}$. Various enzymes are also secreted by the liver to ensure the proper and prompt distribution of various biological compounds when needed. These enzymes are manufactured by the liver and an increase in the proportion of enzymes may be a result of liver problems. Of all the liver enzymes, aspartate aminotransferase (AST) and alanine aminotransferase (ALT) are two of the enzyme central to such an investigation. When used intensely, AST and ALT can identify liver toxicity, liver disease, or liver damage. This present research work determines the effect of extract of $P$. biglobosa on liver function enzymes of Wistar rats.

\section{MATERIALS AND METHODS}

This research work was carried out in the Department of Anatomy and Forensic Anthropology of the Cross River University of Science and Technology, Okuku, Cross River State of Nigeria. It was carried out in September 2020.

Extract preparation- Fresh seed of $P$. biglobosa was supplied from a market in Makurdi, Benue State of Nigeria. The seeds were examined and confirmed by the Herbarium unit of the Department of Botany, University of Calabar, Calabar in Nigeria and were dried at room temperature. The dried seed samples were then blended and $165 \mathrm{~g}$ of blended seed samples was gotten. The blended seed was macerated with $1500 \mathrm{mg}$ of distilled water and the mixture was left for 48 hours at $20^{\circ} \mathrm{C}$. The mixture was filtered using Whatmans filter paper.

Experimental animals- Twenty-one (21) adult male Wistar rats were purchased from the animal house of the Department of Human Anatomy and Forensic Anthropology, Cross River University of Technology, Okuku, Yala in the Cross River State of Nigeria. The animals were divided into three (3) groups and were kept in perspex cages to acclimatize for 21 days before commencement of administration under a controlled light routine, (12 hours light and 12 hours dark cycle) and were fed with growers' vital feed and water ad libitum. They were weighed before the experiment using a digital weighing balance.

Termination of the experiment- At the end of administration (30 days), the animals were sacrificed by cervical dislocation ${ }^{[18]}$. Blood was collected through cardiac puncture from the left ventricle into labelled specimen bottles for animals in each group. Serum was separated by centrifugation for 5 minutes at $100 \mathrm{rpm}$ and used for assay to determine the enzymes- aspartate aminotransferase (AST) and alanine aminotransferase (ALT) ${ }^{[19]}$. The liver of each animal was removed and rinsed with normal saline (Table 1 ).

Table 1: Experimental design across all groups used for this study

\begin{tabular}{cccc}
\hline Group & $\begin{array}{c}\text { P. biglobosa } \\
\text { dose }(\mathbf{m g})\end{array}$ & $\begin{array}{c}\text { Duration } \\
\text { (days) }\end{array}$ & $\begin{array}{c}\text { Route of } \\
\text { administration }\end{array}$ \\
\hline $\begin{array}{c}\text { A } \\
\text { (Control) }\end{array}$ & $\begin{array}{c}\text { Fed with } \\
\text { normal } \\
\text { saline and } \\
\text { feed }\end{array}$ & 30 days & Oral \\
$\begin{array}{c}\text { B (Low } \\
\text { dose) }\end{array}$ & $\begin{array}{c}300 \\
\mathrm{mg} / \mathrm{kgbw}\end{array}$ & 30 days & Oral \\
$\begin{array}{c}\text { C (High } \\
\text { dose) }\end{array}$ & $\begin{array}{c}500 \\
\mathrm{mg} / \mathrm{kgbw}\end{array}$ & 30 days & Oral \\
\hline
\end{tabular}

Histological studies- The liver tissue obtained from each group were preserved in sample bottles with $10 \%$ buffered formalin for 72 hours for effective tissue penetration and fixation. Thereafter, tissues (liver) were placed in ascending grades of ethanol for dehydration at two changes each $(50 \%, 70 \%, 95 \%$, and $100 \%$ ethanol) with each change lasting for one hour. After dehydration, the liver tissues were cleared in three changes of xylene each lasting for (30) thirty minutes and impregnated in molten paraffin wax at $58^{\circ} \mathrm{C}$. Tissues were embedded in molding blocks and allowed to dry after which there were taken to the microtome where tissue blocks were mounted for sections to be cut at 5 microns and floated in a floatation bath at $28^{\circ} \mathrm{C}$. Sections were picked using a clean slide rubbed with egg albumen and dried in a laboratory incubator. The next day, sections were stained using routine Hematoxylin and Eosin stains ${ }^{[6]}$. 
Determination of Liver Enzymes- Determination of serum aspartate aminotransferase and alanine aminotransferase was carried ${ }^{[7]}$.

Statistical Analysis- Obtained data were analyzed using One Way of Variance (ANOVA) together with post hoc test at $P<0.05$. Statistical Package for Social Science Scientific Solution (SPSS) software version 20.0 was used for the analysis.

\section{RESULTS}

Effect of Aqueous Seed Extract $P$. biglobosa on body weight of Rat- At the end of the research, the mean bodyweight of the animals in the control group was $145.0 \pm 3.225 \mathrm{~g}$ against its initial body weight of $101.8 \pm 2.273 \mathrm{~g}$, whereas the mean body weight of the treatment group (low dose and high dose) were $185.2 \pm 4.790 \mathrm{~g}$ and $156.6 \pm 4.226 \mathrm{~g}$ as against $112.5 \pm 1.677$ $\mathrm{g}$ and $120.5 \pm 1.891 \mathrm{~g}$, respectively. The study shows an observable difference between the low dose and high dose groups at $\mathrm{p}<0.01$ (Fig. 1).

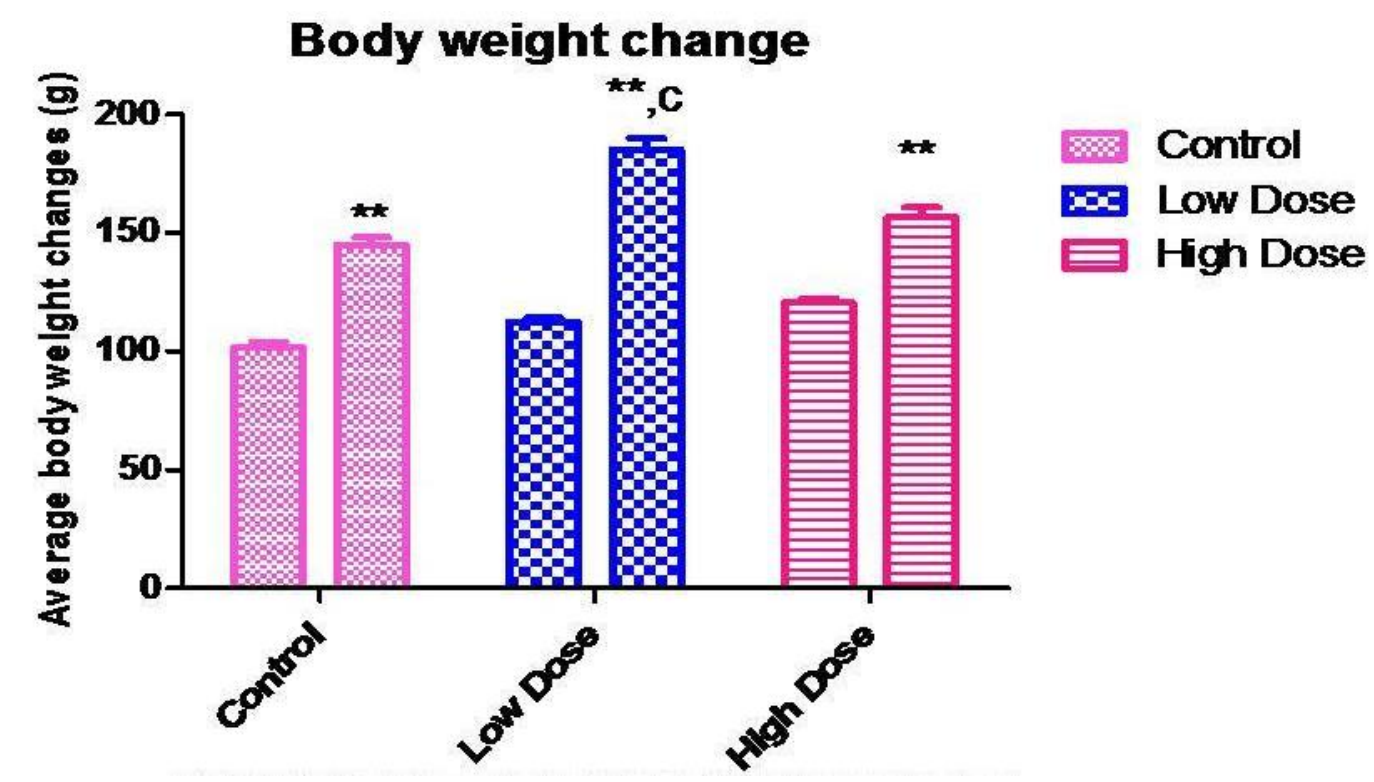

Fig. 1: $P$. biglobosa extract effect on average body weight changes in Wistar Rats. Ues is expressed in mean $\pm S E M n=5$. $\mathrm{C}=\mathrm{P}<0.01$ vs High dose

Table 2: Comparison of mean initial and final body weight of animals used for this study

\begin{tabular}{ccc}
\hline Groups & Initial body weight & Final body weight \\
\hline Control & $101.8 \pm 2.273$ & $145.0 \pm 3.225^{\mathrm{a}}$ \\
Low dose & $112.5 \pm 1.677$ & $185.2 \pm 4.790^{\mathrm{a}}$ \\
High dose & $120.5 \pm 1.891$ & $156.6 \pm 4.226^{\mathrm{a}}$
\end{tabular}

Values are expressed as mean $\pm S E M n-5, p<0.01^{a=}$ significantly different from the initial body weight at $p<0.01$. 


\section{Histological Analysis}

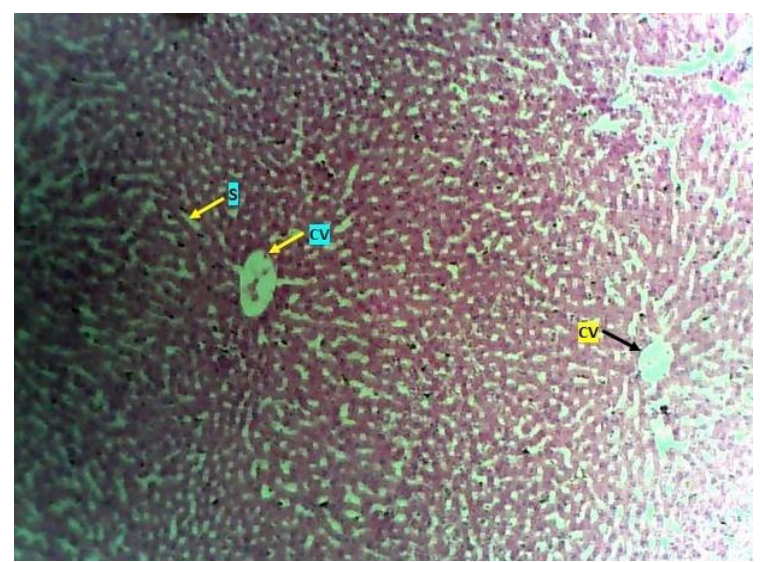

Fig. 2a: Control of the liver showing cords $(\mathrm{H})$ and central vein. Hepatocytes and sinusoids (S) appear normal H \& E X40

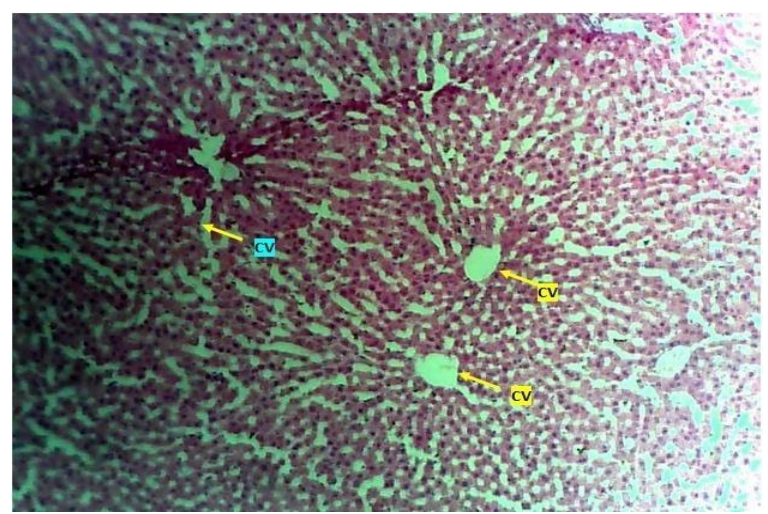

Fig. 3a: Low dose of the liver showing central veins (CV) and mildly dilated sinusoids (DS) H\&E. X40

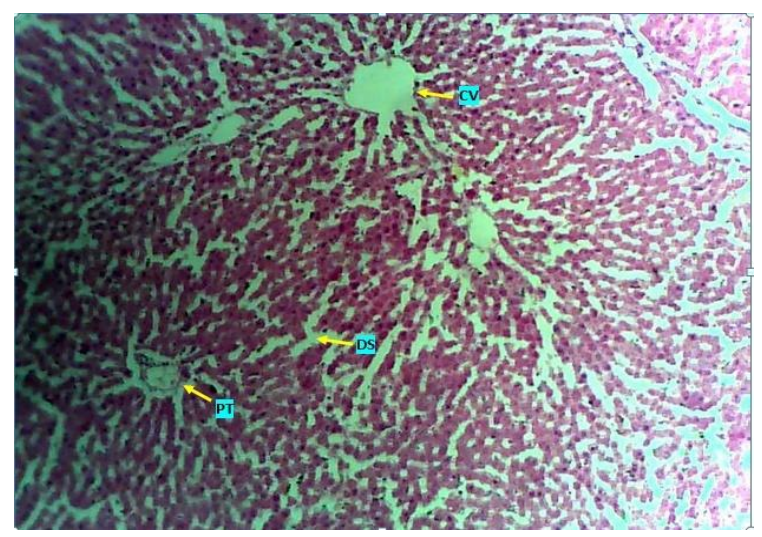

Fig. 4a: High dose of the liver showing central vein (CV, a portal tract (PT) with dilated sinusoids (DS). A prognosis of hepatic hypertension H\&Ex40

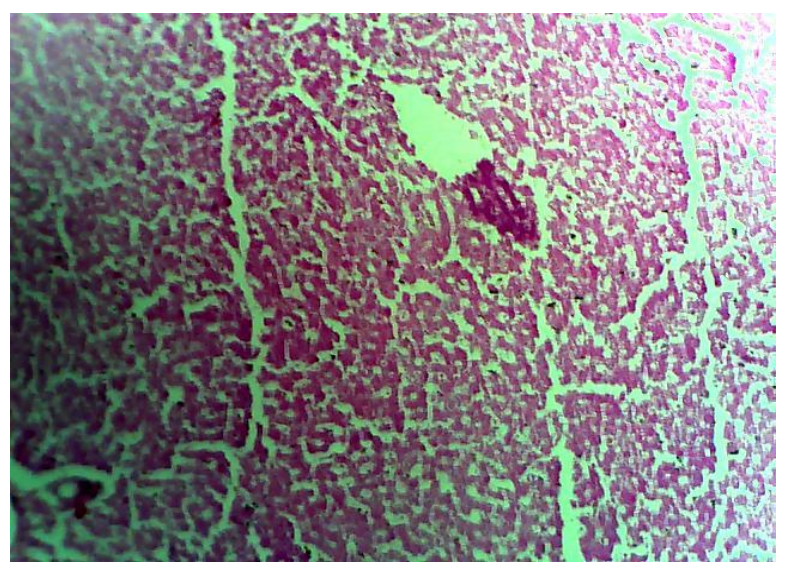

Fig. 2b: Liver of control group showing marked PAS staining on predominant hepatocytes but little or no staining on cytoplasmic clearing X40

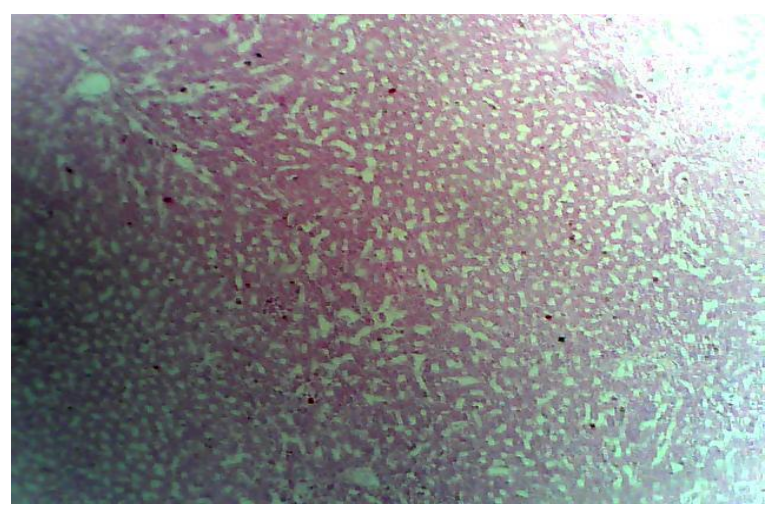

Fig. 3b: Section of the liver of low dose group showing mild PAS staining

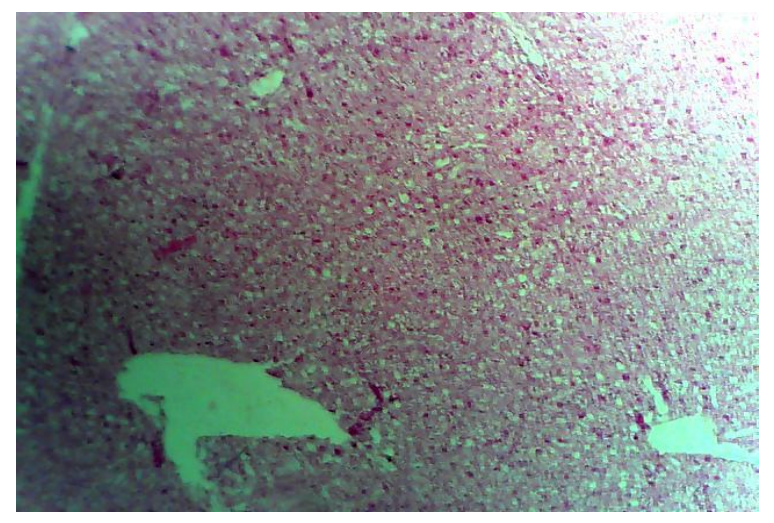

Fig. 4b: Section of the liver of high dose showing cytoplasmic clearing not staining PAS, and remnant hepatocytes giving moderate staining 


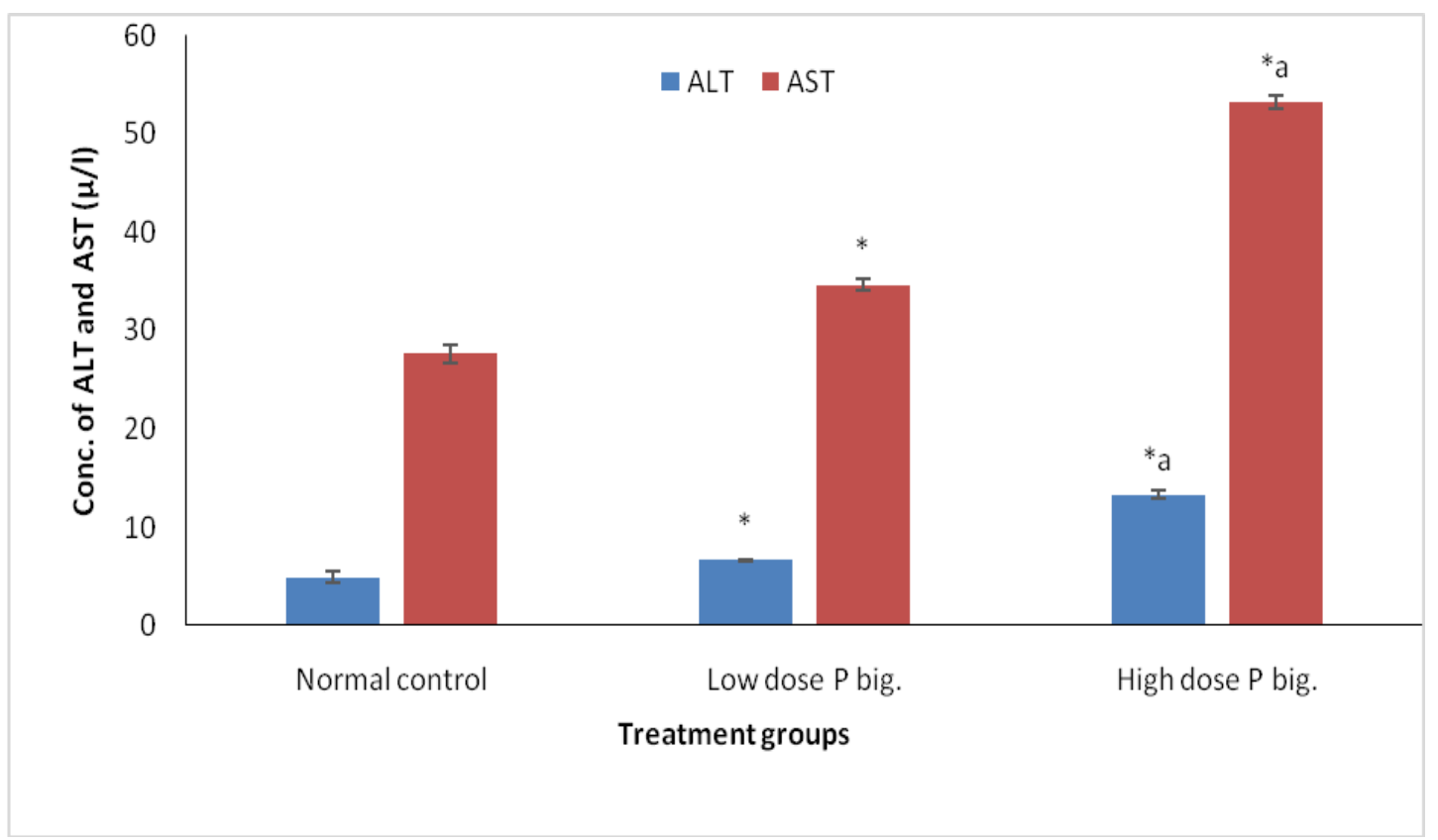

Fig 5: Effect of seed extracts of $P$. biglobosa on liver enzymes ALT \& AST of experimental animals

\section{Effect of Aqueous Seed extract of $P$. biglobosa on Liver} enzymes- Result of this analysis shows variation in all the groups. Groups treated with extract in low dose and high dose, respectively show a significant difference at $p<0.05$, when compared to normal control.

Values are expressed as Mean+SEM ( $n=5$ rats per group). The same colour at $\mathrm{P}<0.05,{ }^{*}=$ Significantly different from Normal Control, a = significantly different from Low dose $\mathrm{P}$ big. Normal control= group, which received normal saline, Low dose $\mathrm{P}$ big= group, which received $300 \mathrm{mg} /$ Kgb.w of $P$. biglobosa (low dose) and High dose $P$. biglobosa $=$ group, which received $500 \mathrm{mg} / \mathrm{Kg} \mathrm{b.w}$ of $P$. biglobosa (high dose).

Table 3: Seed extract effect of $P$. biglobosa on liver enzymes of experimental animals

\begin{tabular}{ccc}
\hline Groups & ALT & AST \\
\hline Normal control & $10.95 \pm 0.52^{*}$ & $18.67 \pm 0.93^{*}$ \\
$\begin{array}{c}\text { Low dose } P . \\
\text { biglobosa }\end{array}$ & $6.65 \pm 0.12^{\mathrm{a}}$ & $14.68 \pm 0.59^{\mathrm{a}}$ \\
$\begin{array}{c}\text { High dose } P . \\
\text { biglobosa }\end{array}$ & $8.31 \pm 0.42^{\mathrm{b}}$ & $13.26 \pm 0.64^{\mathrm{b}}$ \\
\hline
\end{tabular}

Values are expressed as Mean \pm SEM ( $n=7$ rats per group). In the same column, different characters= significantly different at $\mathrm{P}<0.05$. Legend: Normal control= group, which received normal saline, Low dose $P$. biglobosa= group, which received $0.3 \mathrm{ml} / \mathrm{Kg}$ b.w of $P$. biglobosa (low dose) and High dose $P$. biglobosa $=$ group, which received $0.5 \mathrm{ml} / \mathrm{Kg}$ b.wt of $P$. biglobosa (high dose).
Table 4: Effect of seed extract of $P$. biglobosa on serum enzymes of experimental animals

\begin{tabular}{ccc}
\hline Groups & ALT & AST \\
\hline Normal control & $8.95 \pm 0.52^{*}$ & $15.67 \pm 0.93^{*}$ \\
$\begin{array}{c}\text { Low dose } P . \\
\text { biglobosa }\end{array}$ & $6.65 \pm 0.12^{\mathrm{a}}$ & $12.68 \pm 0.59^{\mathrm{a}}$ \\
$\begin{array}{c}\text { High dose } P . \\
\text { biglobosa }\end{array}$ & $7.31 \pm 0.42^{\mathrm{b}}$ & $10.26 \pm 0.64^{\mathrm{b}}$ \\
\hline
\end{tabular}

Values are expressed as Mean+SEM ( $n=5$ rats per group). In the same column, different characters= significantly different at $P<0.05$. Legend: Normal control= group, which received normal saline, Low dose $P$. biglobosa= group, which received $300 \mathrm{mg} / \mathrm{KgBwt}$ of $P$. biglobosa (low dose) and High dose P. biglobosa= group, which received $500 \mathrm{mg} / \mathrm{KgB} . w t$ of $P$. biglobosa (high dose).

\section{DISCUSSION}

Phytochemicals have great antioxidant potential and are of great interest due to their beneficial effects on the health of human beings, and they give immense health benefits to consumers. The plant kingdom represents a large reservoir of biologically active compounds with varieties of the chemical structure and protective/ preventive properties (phytochemicals). These phytochemicals, often secondary metabolites present in smaller quantities in higher plants include flavonoids, alkaloids, steroids, terpenoids, tannins, and many others 
${ }^{[8]}$. Despite ample literature, there are very few marketed formulations with excellent hepatoprotective or hepatoprotective activities. There is a need for authentication and scientific investigations of the hepatoprotective claims of Ayurvedic or traditional herbal formulations for their wider acceptance ${ }^{[9]}$.

At the end of this research, the bodyweight of the rats represented in Table 1 in various groups showed variation. The result reveals that the aqueous seed extract of $P$. biglobosa administered at a low dose of $(0.3$ $\mathrm{ml}$ ) caused a very significant increase $(p<0.01)$ in the bodyweight of the low dose group treated animals when compared to the high dose and control group, respectively. The less increase in body weight of the high dose treated animals might be as a result of the presence of tannin, a phytochemical which is present in $P$. biglobosa ${ }^{[10,11]}$. According to a report by Silanikove and Serge ${ }^{[12]}$ on the effect of Tannin on Feed Intake, Body Weight Gain and Health of Goats, high tannins concentration reduces voluntary feed intake and nutrient digestability. Tannins reduce body weight gain because of reduction in protein digestibility. Furthermore, the reduction in growth is the function of the interaction of tannin in the extract with food proteins, digestive enzymes and microbes. This result suggests that chronic consumption or administration of the extract at higher amounts or doses over a long duration may affect body weight gain.

The microscopic examination of a section of the liver from the control group revealed normal cytoarchitecture of the liver with hepatic cords and central veins. Hepatocytes and sinusoids also appear normal. Liver tissue from animals in the low group shows a liver cytoarchitecture with central veins and mildly dilated sinusoids. While a section of liver tissue from animals that were administered $0.5 \mathrm{ml}$ of the extract (high dose) shows central vein, a portal tract with dilated sinusoids. Sinusoidal dilation is a prognosis of hepatic hypertension. This observation reveals a dose-dependent distortion in the liver architecture when compared to the normal control group. This result agrees with observations in a dose-dependent distortion in liver cytoarchitecture using Gnetum africanum at various doses ${ }^{[13]}$.

Histochemical studies of a photomicrograph of a section of the liver tissue of control reveal a marked PAS staining on predominant hepatocytes but little or no stains on cytoplasmic clearing, which is an indication of a normal cytoarchitecture of the liver hepatocytes and a normal glycogen concentration in the liver. That of the low dose group reveals a mild Periodic Acid Schiff stain. While a section of liver tissue of high dose reveals no Periodic Acid Schiff (PAS) staining of cytoplasmic clearing and moderate staining of remnant hepatocytes. The result for the treated groups reveals a varying reduction in glycogen distribution, which is an indication that the extract could have inhibited glycogen synthesis, which may lead to interference in glycogenolysis. A dysfunction in glycogenolysis can lead to a variety of diseases including glycogen storage diseases (GSD) and lysosomal storage diseases. Disruptions in glycogenolysis frequently effectuate the dysfunction of organs like the liver, skeletal muscles and kidney ${ }^{[14,15]}$.

Alanine and aspartate transferases (ALT and AST) are well-known transaminases used as biomarkers to predict possible toxicity in the blood of sick animals ${ }^{[16]}$. These enzymes are only released into the blood an insignificant amount from the cytosol and sub-cellular organelles when hepatic injuries occur and biochemical analysis shows a significant increase in aspartate aminotransferase and alanine aminotransferase (AST and $A L T)$ levels when compared with normal control $(P<0.05)$. This result is in line with that of Obeten et al. [17], who observed a dose-dependent increase of AST and ALT using aqueous extract of Theobroma caca on adult wistar rats.

\section{CONCLUSIONS}

In this study, the morphology, histology and some biochemical parameters have been examined after exposure to different doses of the extract concerning control. The result revealed that repeated exposure of $P$. biglobosa elevated biochemical indices and altered cellular architecture in a manner reminiscent of hepatic injury.

The severity of rat biochemical indices and hepatocellular morphology shows correlation with increased dosage, thus the administration of the extract at various doses may hurt the biochemical and morphology profile of treated Wistar rats.

\section{CONTRIBUTION OF AUTHORS}

Research concept- Dr. Kebe Edet Obeten

Research design- Dr. Kebe Edet Obeten

Supervision- Dr. Kebe Edet Obeten 
Materials- Ajaba Anthony, Ozioko Onyinye Mary, Ozioko Uche Sebastine

Data collection- Mba Christian Ejuiwa, Dr Kebe Edet Obeten and Ajaba Anthony

Data analysis and Interpretation- Mba Christian Ejuiwa, Ozioko Onyinye Mary

Literature search- Ajaba Anthony, Ozioko Uche Sebastine Writing article- Mba Christian Ejuiwa, Dr Kebe Edet Obeten

Critical review- Mba Christian Ejuiwa

Article editing- Mba Christian Ejuiwa

Final approval- Dr. Kebe Edet Obeten

\section{REFERENCES}

[1] Firew B. Ethnobotanical Studies of Medicinal Plants used to treat Human and Livestock Ailments in Southern Nations, Nationalities and Peoples' Region, Ethiopia: A Systematic Review. J Plant Stud., 2019; 8(1): 1-9.

[2] Girish H, Satish S. Antibacterial Activity of Important Medicinal Plants on Human Pathogenic Bacteria: A Comparative Analysis. World Appl Scis J., 2008; 5(3): 267-71.

[3] Okwu D, Omodamiro O. Effect of hexane extract and phytochemical content of Xylopiaa ethiopica and Ocimum gratissimum on uterus of guinea pig. Biol Res., 2008; 3: 40-44.

[4] Campbell-Platt, G. African locust beans (Parkia spp) and its West African Fermented Food product, 'Dawadawa'. Ecol Food Nutr., 1988; 9: 123.

[5] Liangyou R. Energy metabolism in the Liver. Compr Physiol., 2014; 4(1): 177-97.

[6] Cardiff RD, Miller CH, Munn RJ. Manual hematoxylin and eosin staining of mouse tissue sections. Cold Spring Harb Protoc., 2014; 6: 655-58.

[7] Karia LR, John BA. Allred. Direct Enzymatic Procedure for the determination of liver glycogen. Anal Biochem., 1974; 58(2): 414-21.

[8] Yancui H, DiXiao-Britt M, Burton F, Indika E. Chemical Changes of Active Biochemicals during Thermal Processing. Ref Mod Food Sci., 2016; 6(7): 337-40.
[9] Tejaswi C, Aniket K. A review on drug induced hepatotoxicity and alternative therapies. J Nut Health Food Sci., 2019; 7(3): 1-29.

[10]Yuye W, Xianran Li, Wenwen X, Chengsong $Z$, Zhongwei L, et al. Presence of tannins in sorghum grains is conditioned by different natural alleles of Tannin. PNAS, 2012; 109(26): 10281-86.

[11]Builders M, Wannnang N, Aguiy J. Antiplasmodial activites Parkia biglobosa: In vivo and in vitro studies. Annu Bio Resh., 2011; 2: 8-20.

[12]Silanikove N, Serge Yan L. Analytical approach and effects of condensed tannins in carob pods (Ceratonia siliqua) on feed intake, digestive and metabolic responses of kids. Livestock Sci., 2006; 99(1): 29-38.

[13]Obeten K, Ubangha A, Tiku A, Okafor A. Effect of Aqueous Extract of Gnetum africanum (Afang) Leaves on the Liver and Liver enzymes of Adult Wistar Rats. J Anatomoical Sci., 2019; 10(1): 57-61.

[14]Ellingwood $S$, Cheng $A$. Biochemical and clinical aspects of glycogen storage diseases. J Endocrinol., 2018; 238(3): R131-R41.

[15]Kanungo S, Wells K, Tribett T, El-Gharbawy A. Glycogen metabolism and glycogen storage disorders. Ann Transl Med., 2018; 6(24): 474.

[16]Chiarelli A, Casadei EP, Siliprandi L. Alanine and aspartate aminotransferase serum levels in burned patients: a long-term study. J Trauma, 1987; 27(7); 790-94.

[17] Kebe E, Victor F, Obo U, Ayi C. Morphological and Biochemical Effect of Theobroma cacoa on Liver of wistar Rats. EC Pharmacol Toxicol., 2019; 7(12): 1-9.

[18]Office of Research support and Compliance. Guidelines for use of cervical dislocation for rodent Euthanasia. 2013; Available at: https://research.utexas.edu/wp.

[19]Edoardo G, Roberto T, Vincenzo S. Liver enzyme alteration: a guide for clinicians. CMAJ-JAMC, 2005; 172(3): 367-79. 